\title{
Some Origins of Development Economics
}

\section{Douglas Rimmer}

Development economists have been incurious about the origins of their subject; little has been published on this topic (Arndt 1972) and it is perhaps usual to suppose that the subject began with the political reordering of the world that followed the second world war (Simpson 1976). This article looks at the period from about 1935 to 1945 , when fairly evident harbingers can be discerned in reports of international agencies, writings of students of international economic relations, and policies and pronouncements of some national governments. As often happens in exploring the genealogy of ideas, ancestors are identified who would not be entirely welcome at the hearths of their progeny alive today.

\section{Basic needs}

The starting point is the world depression of the 1930s and the contemporaneous dissemination of nutritional discoveries. Following appearance of a seminal report to the Health Organisation of the League (Burnet \& Aykroyd 1935) there was inaugurated at Geneva an international food movement (Black 1943), the purpose of which was to raise nutritional levels in order to engineer recovery in agricultural export markets. The principal broker for this marriage of health and agriculture was the Australian politician $\mathbf{S}$. M. (later Lord) Bruce; his advisers were the economist F. L. McDougall and the nutritionist and social reformer John Boyd Orr. Through these men and the reports engendered by their campaign (League of Nations 1935, 1937a; ILO 1936) the line of descent is clear to the postwar Food and Agriculture Organisation of the UN (McDougall 1943; Hambidge 1955).

The notion of scientifically establishing requirements of health and human development to show the inadequacy of current consumption levels was quickly extended from food to other universal human wants, such as for housing, clothing, schooling and medical care. Again the Australian delegation led by Bruce took the initiative at Geneva, proposing enquiry into "measures of a national or inter-national character for raising the standard of living". On the basis of subsequent reports and memoranda (McDougall 1937, 1938: ILO 1938; League of Nations 1938) the terrain and objectives of the nutrition campaign begun in 1935 were much extended. Its core was still nutrition-because food appeared the first necessary of life, or food requirements were those that could be most exactly specified, or food markets those that the campaigners wanted most to expand. But norms of hygiene and norms dependent on public approbation were being formulated alongside those of nutrition; living standards in general instead of food consumption in particular were being measured and compared; and in place of a policy of producing economic recovery through better feeding and freer trade in the agricultural staples there were suggestions that consumption as a whole should be manipulated so as to control fluctuations in world economic activity and perhaps also (with an eye particularly to Japanese exporting) to relieve international political tensions.

To raise sub-standard levels of consumption, income had to be redistributed in cash or kind in favour of the poor. For example, the Mixed Committee of the League attached much value to free school milk and meals (League of Nations 1937a: 42-43). This was the kernel of a far larger issue. If schooling itself had been socialised in many countries, why should not also feeding, the need for which was yet more fundamental and more precisely definable by science? Ought not food supply to become another public service or utility, distributed in accordance with physiological needs and charged at nominal prices, as had already happened, it was believed (Burnet \& Aykroyd 1935: 459), in Soviet Russia? And since the nutritional needs of a human being had as much validity in, say, rural China as in Glasgow, ought not this detachment of food from the market to be worldwide rather than confined in national boundaries? A world population nourished in accordance with the laws of physiology, the supplies of food to meet this criterion bought and distributed publicly, was both a nutritional ideal and the ultimate means of absorbing agricultural capacity. Just such a prescription were Boyd Orr's Proposals for aWorld Food Board (FAO 1946; Boyd Orr 1966), the apotheosis of the international food movement, submitted to the second FAO conference in 1946. Obviously, even more radical implications followed from adding to food other "objective elements in the standard of living" to define the scientifically established birthrights of all men. 
These implications attracted many who were untouched by the socialist ethnic. In the right degree and places, socialism was perceived good for business. With economic capacity underemployed and confidence in economic mechanisms lost, Geneva in the 1930 s provided common ground for both scientists and trade unionists moved by collectivist ideals and inclinations, and diplomatists moved by pressure to find larger and more secure markets and better remuneration for producers of foodstuffs and manufactures. This harmony of aspirations required an understanding of how socialist measures were to be financed. Most potent and appealing of the possibilities canvassed was the notion that they would pay for themselves, that raising the effective demand of the poor need carry no opportunity costs in a world of 'potential plenty'. Plenty was held to be potential not so much in underemployed capacity, as some critics may have supposed (Clark 1940: 3-4; Hayek 1944: 73) as in incomplete realisation of the productive powers of science (see, e.g., Burnet \& Aykroyd 1935: 368-70)-though this scarcely strengthened the basis of the doctrine.

Between this living-standards movement of the 1930s and the now fashionable 'basic-needs approach' to development (UN 1972, 1973; ILO 1976; Jolly 1976; Lisk 1977) are obvious parallels, if that is not too mild a term, and it is presumably no accident that the campaign has been revived while the world has been experiencing its worst economic recession since the 1930s. The new, or supposedly new, approach has involved a retreat from treating increase in the estimate of GNP per capita as the sovereign aim of development. How did the campaigners of the 1930 s avoid that conceptualisation of their purpose? Briefly, they did not accept the 'national equation' (Röpke 1935) without whose intercession the statistic of GNP per capita is meaningless as an indicator of individual welfare. Socialists they were all in more or less degree; but not National Socialists.

\section{World development programmes}

Ominous interpretations of the depression were offered in the later 1930s. Keynes's vision of the arteriosclerotic economy became analytically elaborated in his General Theory (1936), while in the USA explanations of 'secular stagnation' were argued most notably by Alvin Hansen $(1938,1941)$. By the time of the war, the notion that the more mature economies had reached a stage in which deficiency of investment demand was endemic was almost as familiar as the idea that they were subject to epidemic instability. World development programmes, or plans for international capital flows for the industrialisation of 'undeveloped areas' of the world, were proposed in the early 1940s mainly as a new frontier for investors, though the possibility was also discussed of using them as a counter-cyclical device. Much the fullest study of these plans is the ILO report on World Economic Development (1944), written by Eugene Staley, though there are many earlier contributions (Staley 1939, 1941, 1942; Durbin 1942; Condliffe 1943; Bryce 1943; Rosenstein-Rodan 1944) and the primacy was sometimes acknowledged of Sun Yat-Sen who, a generation earlier, had offered China as "the 'Economic Ocean' capable of absorbing all the surplus capital as quickly as the Industrial Nations can possibly produce" (1943: 6).

A striking indication of the contemporary understanding of world development programmes is Staley's method of estimating their order of magnitude. He did not work backward from target rates of growth in per capita income to aid requirements, as was later to become the practice, by making assumptions about capital coefficients, domestic savings and population growth. Instead he estimated the absorptive capacity for capital of the undeveloped areas on the basis of Japanese performance since 1900 . The purpose was not to show the magnitude of the sacrifice the mature economies would have to make to develop the undeveloped areas but the scale on which they might be disembarrassed of redundant savings. It appeared the amount was not so great as to make unnecessary domestic measures to overcome an excessive saving propensity. Moreover, only a generation or two of grace would be obtained by world development; the return flow of interest and capital repayments would eventually exceed the outflow, aggravating the problem of maintaining full employment unless rejuvenation had been accomplished by domestic policies in the meantime (ILO 1944: ch IV).

This argument assumed that the capital would flow on commercial terms. Indeed, there was much confidence that capital at the margin would be more productive in undeveloped areas than in countries already rich in assets (Bryce 1943: 364; ILO 1944: 112). The failure of experience generally to bear out this expectation, coupled with the failure of either secular stagnation or a cyclical slump to recur after 1945, extinguished any economic case for world development programmes. It is therefore ironical that such programmes were launched and became part of the 
economic scenery of the postwar world. The explanation is that they served foreign policies. From the beginning there had been ambivalence about the terms on which capital should be transferred. It seemed out of keeping with the humanitarian spirit of a new world order that the poor should be charged market rates for the superfluity of the rich (Durbin 1942; Boyd Orr 1942: 58,78 ). It might even seem dangerous not to give freely and so avert the disaffection of the poor (Rosenstein-Rodan 1944). Recognition that international capital transfers on concessional terms or with non-commercial motives would be made to serve national interests-as had happened already in the US Export-Import Bank (Whittesley 1939; Patterson 1943)-was avoided by supposing that the programmes would be entrusted to supra-national authorities (Meade 1940; Corbett 1942; Condliffe 1943). In retrospect it seems an extraordinary failing that the political character of the postwar world, with its multiplication of sovereign entities, was so much mistaken. But they were heady days, when it was possible for a future President of Italy to write that the only sure outcome of the war was the disappearance of the anachronistic sovereign state (Einaudi 1940).

\section{Have-not nations}

Not only in the years following the second world war but also in those immediately preceding it disparities between 'have' and 'have-not' nations were widely believed to be critical for peace and security throughout the world (RIIA 1936, 1938). Membership of the two categories was not the same in the two periods. Nor was the definition of what was possessed or lacked. In the 1930s there were only three have-nots-Germany, Italy and Japan-and what they lacked was not the difference between their own and other nations' income per head but raw materials purchasable in their own currencies, and colonies from which such materials might be obtained.

The prewar state of national want nevertheless presaged the postwar. It implied a foreign exchange gap between the means and ends of the afflicted government. It denoted an economy unbalanced in its structure and unable to satisfy rising expectations. It identified a state disadvantaged and handicapped as compared with others, relatively deprived, victim of past political settlements; expressing vociferously its dissatisfaction with the international economic order and the laws, conventions and distribution of power supporting that order; and demanding concessions in its favour by states better off than itself.
Like the have-nots of the 1930s, those of the postwar world perceived their difficulties to lie in the inadequacy of the range of resources at national disposal. The old have-nots, as industrialised countries, were conscious of their lack of raw materials. The new have-nots, most of which exported raw materials, perceived their want of manufacturing industry. Without raw materials, the old have-nots could not employ their people productively, raise living standards, establish true national independence and take their rightful places in the world community. Without manufacturing, the new have-nots were similarly impeded.

Buying the products of the missing resources from other countries was no solution. It produced damaging relationships of dependence on foreign powers: it precluded economic autonomy without which political independence was but a facade. Moreover, the means of buying foreign products were deemed to be hardly won. For the have-nots of the 1930s the special difficulties of earning foreign exchange were held to result from restrictions in international trade and payments (League of Nations 1937b, 1946; Robbins 1939). For the later generation other explanations were devised. Their exports had abnormally unstable prices, or prices subject to secular deterioration in relation to prices of the imports received in return, or earnings that must lag behind income growth in the markets they supplied or that were inveterately depressed relatively to import costs by 'unequal exchange' or by technological disparities. So the new havenots wanted not the products of manufacturing but the capacity to make the products, just as the old had wanted mines and plantations rather than the industrial materials they produced.

Another parallel is that just as in the 1930s there were industrialised countries without colonies that did not experience the difficulties of Germany, Italy and Japan in obtaining sufficient raw materials because they followed different economic policies (RIIA 1936: 11, 31-32; Ohlin 1936: 142), so in the postwar period there were also underdeveloped countries that looked outward rather than inward (Myint 1967) and did not suffer the constraints characteristic of their class in securing international purchasing power.

The pre-war conception of national deprivation is all but forgotten, obliterated by sudden recognition of who the 'real have-nots' were (PEP 1942: 7). Recalling this unremembered forbear suggests that have-not status might be something chosen or sought by governments rather 
than thrust upon them by circumstance, and that the numerous brood of have-nots that appeared after the war filled a category of diplomacy rather than, as was generally supposed, social science (Rimmer 1979).

\begin{abstract}
Absolutism
This brief survey has barely hinted at the most persistent and powerful strain in development economics. It is the strain implanted by European governments of the 1930 s that mobilised economic resources for national ends. Thus to orchestrate a 'national economy' was regarded at the time as appropriate to preparation for war rather than to the raising of welfare. But there was an easy passage to the belief that the totalitarian methods were usable for benevolent purposes (Balogh 1942: 57), including the development of underdeveloped countries. Indeed, by about 1950 it was evidence of eccentricity to suggest that such development was possible except by concerted social effort, governmental will-power to impose collective sacrifices, bureaucratic coordination of economic life, deliberate manipulation of popular emotions, and assertion of national autonomy (UN 1951). So the physiognomy of the European dictatorships reappeared in the state machineries of Asia and Africa. The new nations suffered the inevitable consequences of accepting a single overriding purpose. Their governments became parochial in their conceptions, jealous of their rights, sure of their responsibilities and absolutist in their ideologies.
\end{abstract}

\section{References}

Arndt, H. W., 1972, “Development economics before 1945", in J. Bhagwati and R. S. Eckaus (eds.), Development and planning: essays in honour of Paul Rosenstein-Rodan, George Allen and Unwin, London

Balogh, Thomas, 1942, "War economics and peace economics", in The economic basis of peace, National Peace Council, London

Black, John D., 1943, "The international food movement", American Economic Review, vol XXXIII

Boyd Orr, Lord, 1942, Fighting for what?, Macmillan, London

-1966, As I recall, MacGibbon and Kee, London
Bryce, R. B., 1943, "International aspects of an investment program", in S. E. Harris (ed.), Postwar economic problems, McGraw-Hill, New York

Burnet E. and Aykroyd W. R., 1935, "Nutrition and public health", Quarterly Bulletin of the Health Organisation (League of Nations, Geneva), vol. IV

Clark, Colin, 1940, The conditions of economic progress, Macmillan, London

Condliffe, J. B., 1943, Agenda for a postwar world, George Allen and Unwin, London

Corbet, P. E., 1942, Post-war worlds, Institute of Pacific Relations, New York

Durbm, E. F. M., 1942, "A four-point programme", The economic basis of peace, National Peace Council, London

Einaudi, Luigi, 1940, "The nature of world peace", Annals of the American Academy of Political and Social Science, vol. 210

FAO, 1946, Propoasls for a World Food Board, Washington D.C.

Hambidge, Gove, 1955, The story of $F A O$, Van Nostrand, New York

Hansen, Alvin H., 1938, Full recovery or stagnation?, A. \& C. Black, London

-1941, Fiscal policy and business cycles, Norton, New York

Hayek, F. A., 1944, The road to serfdom, George Routledge and Sons, London

ILO, 1936, Workers' nutrition and social policy (Studies and Reports, Series B, no. 23), Geneva

-1938, The workers' standard of living (Studies and Reports, Series B, no. 30), Geneva

-1944, World economic development: effects on advanced industrial countries, by Eugene Staley (Studies and Reports, Series B, no. 36), Montreal

-1976, Employment, growth and basic needs: a one-world problem, Geneva

Jolly, Richard, 1976, "The World Employment Conference: the enthronement of basic needs", ODI Review, 2/1976, London 
Keynes, John Maynard, 1936, The general theory of employment, interest and money, Macmillan, London

League of Nations, 1935, Report of the physiological bases of nutrition by the Technical Commission appointed by the Health Committee, Geneva

-1937a, Final report of the Mixed Committee of the League of Nations on the relation of nutrition to health, agriculture and economic policy, Geneva

-1937b, Report of the Committee for the study of the problem of raw materials, Geneva

-1938, Preliminary investigation into measures of a national or international character for raising the standard of living, by N. F. Hall, Geneva

-1946, Raw-material problems and policies, Geneva

Lisk, Franklyn, 1977, "Conventional development strategies and basic-needs fulfilment: a reassessment of objectives and policies", International Labour Review, vol. CXV

McDougall, F. L., 1937, “Economic appeasement", annex to League of Nations, Economic Committee, Remarks on the present phase of international economic relations (September 1937), Geneva

-1938, "Food and welfare", Geneva Studies, vol. IX

-1943, "International aspects of postwar food and agriculture", Annals of the American Academy of Political and Social Science, vol. 225

Meade, J. E., 1940, The economic basis of a durable peace, George Allen and Unwin, London

Myint, Hla, 1967, “The inward and the outwardlooking countries of South-East Asia", Malayan Economic Review, vol. XII

Ohlin, Bertil, 1936, "Raw materials, markets, overpopulation and colonies", in Joint Committee, Carnegie Endowment/International Chamber of Commerce, International economic reconstruction, Paris
Patterson, Gardner, 1943, “The Export-Import Bank", Quarterly Journal of Economics, vol. LVIII

PEP, 1942, "The future of the colonies", Planning, no. 184

RIIA, 1936, Raw materials and colonies (Information Department Papers no. 18), London

-1938, Germany's claim to colonies (Information Department Papers no. 23), London

Rimmer, Douglas, 1979, "Have-not nations: the prototype", Economic Development and Cultural Change, vol. 27

Robbins, Lionel, 1939, "The economics of territorial sovereignty", in The economic basis of class conflict and other essays in political economy, Macmillan, London

Röpke, Wilhelm, 1935, "Fascist economics", Economica, N.S. vol. II.

Rosenstein-Rodan, P. N., 1944, "The international development of economically backward areas", International Affairs, vol. XX

Simpson, James R., 1976, "The origin of United States' academic interest in foreign economic development", Economic Development and Cultural Change, vol. XXIV

Staley, Eugene, 1939, World economy in transition, Council on Foreign Relations, New York

-1941, "The economic organisation of peace", International Conciliation, no. 369

-1942, "The economic aftermath of the war", International Conciliation, no. 379

Sun Yat-Sen, 1943, The international development of China, 2nd edn. 1929, reissued 1943, Chungking

United Nations, 1951, Measures for the economic development of underdeveloped countries, New York

-1972, Committee for Development Planning, Attack on mass poverty and unemployment, New York

-1973, The international development strategy, New York

Whittesley, Charles R., 1939, "Five years of the Export-Import Bank", American Economic Review, vol. XXIX 